\title{
Sociological Orientation of Islamic Education Perspective of the Quran
}

Ahmad Suhaimi

UIN Maulana Malik Ibrahim

Hemi.latanza@gmail.com

\begin{abstract}
Islamic education as part of the national education system has a purpose want to achieve. In the process, Islamic education is inseparable from the problems faced. In the current postmodern era, Islamic education should be used as a forum the seedbed of tolerance to maintain harmony and peace. The Quran and Hadith as the main source of Islamic education must be reinterpreted and integrated with other approaches. One approach that can be integrated is with internalize socio-cultural values in learning. This approach offers a synthesis to deal with the seeds of intolerance that have begun to grow deep this nation's young generation. It is hoped that internalization of these values will be created social harmony that can be used as provisions by young Muslims in life sociable.
\end{abstract}

\section{Introduction}

Dialogue about education becomes a discussion that is never obsolete in various circles, especially when the existence of education is drawn in the arena of Islamic studies. In general, education can be interpreted as building a system that must be applied integratively in order to improve the quality of human life in all aspects. Judging from the process, education will take place continuously along with the changing dynamics of the sociocultural settings of society from time to time. ${ }^{1}$ In the view of Mulyasa Islamic Education is an effort to plan in preparing human beings to recognize, understand, appreciate, and believe in the teachings of the Islamic religion accompanied by demands to respect other religions in the relationship between religious believers to create unity and national unity. ${ }^{2}$ In line with that Alim believes Islamic education is a planned program in preparing individuals to recognize, understand, appreciate, to believe in the teachings of Islam and followed by guidance to respect other religions in relations between religious communities to realize the unity and integrity of the nation. ${ }^{3}$

\footnotetext{
${ }^{1}$ Hidayat, S., \& Wakhidah, AN (2015). The Concept of Islamic Education Ibn Khaldun Is Relevant to National Education, Profession : Journal of Islamic Studies , 1: 93 (2015), 102. 2005), 76

${ }^{2}$ Mulyasa, E, Competency Based Islamic Religious Education. Band ung: PT Remaja Rosdakarya,

${ }^{3}$ Alim, M, Islamic Education , (Jakarta: Grafindo, 2006)
} 
Lately education is experiencing problems, as revealed by Nashir that the lack of balance between spiritual and intellectual aspects, so that the implications of that education no longer give birth to a universal human being as Caliph on earth, but rather become a pragmatic, individualist, and even materialist man. ${ }^{4}$ Whereas the expected goal in Islamic education is to guide, direct, and educate someone to understand and learn the teachings of the Islamic religion so that they are expected to have intelligence (IQ), emotional intelligence (EQ) and have Spiritual intelligence (SQ) to provision of life towards world success and the hereafter. Eschatological orientation seems so dominant in the discourse of the objectives of Islamic education. Thus, understanding patterns received by the learners tend to the cognitive understanding sich although keceradasan emotional aspect has been considered.

In the social science discourse that tends to fluctuate, the aim of Islamic education needs to be reformed and not just cognitive oriented, given the very multicultural composition of Indonesia's population consisting of ethnic, religious, and cultural diversity. If referring to the discourse, then the aim of Islamic education cannot be ignored anymore, it should refer to the socio-cultural values that become its foundation other than the Quran and al-Hadith, of course.

How important is an education that sees cultural and educational processes that cannot be separated. Education and culture have a very close relationship, where education and culture speak at the same level, namely values. One's way of thinking can be understood by tracing the origins of his conscious actions from social interactions (activities and language used) that are based on his life history. ${ }^{5}$ The sociocultural perspective describes the state of individuals and how their behavior is influenced by specific factors in the surrounding environment with their social culture. A person's development should be studied not only focusing on individuals or the environment, but also on the social and cultural context. ${ }^{6}$

So it becomes important studies about the orientation of Islamic education raised again with a holistic social nuances in the perspective of the Quran. So that Islamic Education does not have the impression of giving birth to generations who are able to improve themselves, but also has value in front of the surrounding community.

\footnotetext{
${ }^{4}$ Nashir, A. (2007). Buya Hamka and Mohammad Natsir on Islamic Education, Journal of AtTa'dib, 3: 1, (2007), 59- 81.

${ }^{5}$ Rohman, M., \& Lessy, Z, " Practicing Multicultural Education through Religiously Affiliated Schools and Its Implications for Social Affairs". Journal of Islamic Education, 6: 1, (2017) , 1-24.

${ }^{6}$ Hasnunidah, N., \& Susilo, H. "Profile of Students' Sociocultural Perspectives in Arguing Basic Biology Courses", In Proceeding Biology Education Conference: Biology, Science, Environmental, and Learning, 11: 1 , (2014), 729- 733
} 


\section{Terminology of Islamic Education}

In the treasury of Islamic education thought, there are many terms used by scholars to provide an understanding of Islamic education. Langgulung in Muhaimin said that Islamic education is at least covered in eight terms, namely; altarbiyah al-diniyah (religious education), $t a$ 'lim al-din (religious teaching), al-ta'lim al-sung (religious teaching), alta ' lim al-Islamy (Islamic teaching), tarbiyah al-muslimin (Islamic education), al-tarbiyah fi al-Islam (education in Islam), al-tarbiyah "inda almuslimin (education among Muslims), and al-tarbiyah al-Islamiyah (Islamic education). However, education experts usually highlight the term from the aspect of differences in tarbiyah and ta' ${ }^{\prime}{ }^{\prime}{ }^{7}$

The term ta' dib is also used in explaining the notion of education besides the two words above. In other words, the term education in the Islamic context generally refers to the terms al-tarbiyah, alta 'dib and al-ta' lim. Of the three terms, the term that is popularly used in the practice of Islamic education is the term al-tarbiyah. While the terms al-ta ' dib and alta ' lim are rarely used. Though both of these terms have been used since the beginning of the growth of Islamic education. ${ }^{8}$

However, in certain cases, all three terms have the same meaning. But essentially, each term has a difference, both textually and contextually. For this reason, it is necessary to put forward a separate description and analysis of arguments from the opinions of Islamic education experts.

\section{a. The term al-Tarbiyah}

The use of the term al-tarbiyah comes from the word rabb. Although this word has many meanings, but the basic understanding shows the meaning of growing, developing, maintaining, caring, managing, and maintaining its preservation or existence. ${ }^{9}$ In another explanation, the word al-tarbiyah comes from three words, namely: First, rabba-yarbu which means to increase, grow and develop (QS Ar Ruum / 30. Second, rabiya-yarba

\footnotetext{
${ }^{7}$ Muhaimin, Islamic Education Paradigm, (Bandung: Teens Rosdakary a, 2002), 36

${ }^{8}$ Abuddin Nata, Islamic Education, (Jakarta: Kencan a Prenada Media Group, 2010), 7

9 Abdul Mujib and Jusuf Mudzakir, Islamic Education, (Jakarta: Kencana Prenada Media Group, 2014), 10-11
} 
which means to be great. Third, rabba -yarubbu means improving, mastering affairs, guiding and maintaining. ${ }^{10}$

Islamic education contained in the term al-tarbiyah consists of four elements of the approach, namely: (1) maintaining and maintaining the nature of students before adulthood (baligh). (2) developing all potential towards perfection. (3) directing all fitrah towards perfection. (4) carry out education in stages. ${ }^{11}$

From the previous presentation, term al-tarbiyah has a very broad meaning in explaining education. Education here regulates maximizing all the abilities that exist in students ranging from birth to adulthood including all the potential they have through education which is done in stages.

\section{b. The term al-Ta'lim}

The term al-ta ' lim has been used since the early period of the implementation of Islamic education. According to experts, this word is more universal than al-tarbiyah or al-ta ' dib. Rasyid Ridha in Ramayulis, interpreted al-ta ' lim as the process of transmitting various sciences to the individual's soul without any restrictions and certain provisions. ${ }^{12}$ argument is based on referring to (QS Al-Baqarah: 151). Sentence wa yu ' allimu hum al-kitab wa al-wisdom in these verses explain more about the activities of the Prophet teaches tilawat al-Qur ' an to the Muslims. According to Abdul Fatah Jalal, what the Apostle did was not just to make Islam able to read, but brought Muslims to the value of tazkiyah an-nafs (self-purification) education from all impurities, thus enabling him to accept al-hikmah and learn everything useful to be known.

Therefore, the meaning of al-ta' lim is not only limited to outward knowledge but includes theoretical knowledge, repeating verbally, knowledge and skills needed in life; orders to carry out knowledge and guidelines for behavior. It can also be said that the term ta' lim is broader in scope and more general in nature. ${ }^{13}$

From the previous explanation, it is known that humans are perfect beings compared to other creatures created by God. Humans have lust and reason that must be used properly. The

\footnotetext{
${ }^{10}$ Sri Miniarti, Islamic Education, (Jakarta: AMZAH, 2013), 29

${ }^{11}$ M. Jinda $r$ Wahyudi, Reason of Qur'an Education, (Yogyakar ta: Apeiron Philotes, 2006), 53

${ }^{12}$ Ramayulis, Islamic Education, (Jakarta: Kalam Mulia 2010), 16

${ }^{13}$ Sri Miniarti, Islamic Education, (Jakarta: AMZAH, 2013), 30
} 
existence of education as a way to empower the mind in achieving happiness in the world and the hereafter, and bring lust in the good direction. So the word ta'lim is broad in scope.

c. The term al-Ta'dib

According to Al-Atas, the most appropriate term to indicate Islamic education is alta'dib. Al-ta'dib means the recognition and gradual recognition that is instilled in humans (learners) about the exact places of everything in the order of creation. With this approach, education will function as a guide to the recognition and recognition of God's proper place in the order of being and personality. ${ }^{14}$

Apart from the debate over the meaning of the three terms above, the terminology of Islamic education experts explains it as follows:

a. Al-Syaibaniy; stated that Islamic education is the process of changing the behavior of individual students in personal life, society and the natural surroundings. The process is carried out by means of education and teaching as a human and professional activity among the many professions in the community. ${ }^{15}$

b. Muhammad Fadhil al-Jamaly; define Islamic education as an effort to develop encourage and invite students to live more dynamically based on high values and noble life. Through this process, students are expected to form perfect personal, both related to the potential of reason, feelings and actions. ${ }^{16}$

c. Ahmad Tafsir; define Islamic education as guidance given by a person so that he develops optimally in accordance with Islamic teachings. ${ }^{17}$

d. Hamka; education is a series of efforts made by educators to help shape the character, character, character, and personality of students, so that he can distinguish what is good and what is bad. Teaching means an effort to fill students' intellectuals with a number of sciences. $^{18}$

\footnotetext{
${ }^{14}$ Ar-Rasyidin and Samsul Nizar, Philosophy of Islamic Education , (Ciputat: PT Ciputat Press, 2005), $30-31$

${ }^{15}$ Abuddin Nata, Islamic Education, (Jakarta: Kenca ma Prenada Media Group, 2010), 28

${ }^{16}$ Abdul Mujib and Jusuf Mudzakir, Islamic Education, (Jakarta: Kencana Prenada Media Group, 2014), p. 26

${ }^{17}$ Ahmad Tafsir, Education in Islamic Perspectives, (Bandu : Ramaja Rosdakarya, 2013), 32

${ }^{18}$ Samsul Nizar, Discussing Intellectual Dynamics and Hamka Thinking about Islamic Education, (Jakarta: Prenada Media Group, 2008), cet. 1st, 111
} 
e. Qardawi; education is a necessity as well as being a necessity of every human being. That is because humans basically have three roles, namely the role of worship, the role as God's representative and the role as the builder of civilization. As a Muslim figure of the modern age who is considered a reformer (reformer) Qardhawi defines Islamic education as a whole human education which includes mind and heart, spiritual and physical, as well as morals and behavior. ${ }^{19}$

Relation to the various definitions that were put forward by experts on Islamic education. So that in practice, Islamic education in Indonesia can be grouped into five types, namely:

a. Islamic boarding school or madrasa diniyah, based on Law no. 20 of 2003 concerning the national education system referred to as formal religious (Islamic) education such as pondok pesantren / madrasa diniyah (ula, wustha, ulya, and ma' had ali) b. Madrasa and further education such as IAIN / STAIN or UIN state Islamic universities that are under the auspices of the religion c. Early childhood education / kindergarten, school / college held under the auspices of Islamic foundations and organizations. d. Islamic studies in schools / madrasas / colleges as a subject or course or study program e. Islamic education in the family or in places of worship, the forum - a forum on Islamic studies, or Islamic education through non-formal education, and informal. ${ }^{20}$

From the above limits it can be concluded that Islamic education is a system that allows a person (students) to direct their lives in accordance with Islamic ideology. Through this approach, he will easily shape his own life in accordance with the values of Islamic teachings that he believes.

\section{Fundamentals of Islamic education}

In order for education to carry out its functions, education requires a basic reference on which to base it. Reference which is the basis for education is the highest value of the outlook on life of a society where education is carried out. In determining the source of Islamic education, Islamic thinkers have several opinions. Abdul Fattah Jalal, for example, divides the source of Islamic education into two types, namely, first, the Divine source, which includes al-Qur'an, al-Hadits, and the universe as verses of kauniyah that need to be

\footnotetext{
${ }^{19}$ Safrudin Aziz, Islamic Education Thought, ( Yogyakarta: KALIMEDIA, 2015), 168.

${ }^{20}$ Muhaimin, Reconstruction of Islamic Education, (Jakarata: PT RAJAGRAFINDO PERSADA, 2013), 15-16
} 
reinterpreted. Second, the source of humanity, namely through the process of human ijtihad from the phenomena that arise and from further studies of Divine sources that are still global. $^{21}$

Other Islamic education experts divide the sources or basic values that are used as references in Islamic education to three, namely al-Quran, al-Hadits, and Ijtihad $^{22}{ }_{-}$Muslim scientists who sought to formulate the form of the Islamic education system demanded by the times, while the solution is not found in the two main sources above. In addition to the above sources, Ayumardi Azra mentions several other sources such as: the words of Friends, the benefit of the community and the values of customs and social habits. ${ }^{23}$ While others also mention Islamic thought, Islamic history and the realities of life. ${ }^{24}$ From the aforementioned opinions, the following will describe some of the things that have become the main sources for Islamic education.

\section{a) Al-Qur'an}

As the Kalama of Allah revealed to the Prophet Muhammad, the Qur'an is the first and foremost source of Islamic education. The Qur'an is a complete guide, a guideline for humans that covers all aspects of human life and is universal. ${ }^{25}$ universality of his teachings encompasses high science and at the same time is a noble case whose essence cannot be understood, except for people who are holy and intelligent. ${ }^{26}$ The Qur'an was revealed by Allah to point people towards a better direction. The Word of Allah :

"And We have not sent down to you al-Kitab (al-Qur'an) but rather so that you can explain to them what they are disputing and become guidance and mercy to the believers" (Qs. Al-Nahl: 64)

The Qur'an occupies the forefront of taking other educational resources. All activities and processes of Islamic education must always be oriented to the principles and values of the Qur'an. In the Quran there are some things that are very positive for the development of

\footnotetext{
${ }^{21}$ Abdul Fatah Jalal, Principles of Islamic Education, Terj. Herry Noer Ali, (Bandung, CV . Dipenegoro, 1988), 143-155

${ }^{22}$ Samsul Nizar, Fundamentals of Islamic Education Thought, (Jakarta: First Media Style, 2001 ), 95.

${ }^{23}$ Azyumardi Azra, Muslim Intellectual Essays and Islamic Education, (Jakarta : Logos Discourse of Science, 1999), 9-10

${ }^{24}$ Rahman Abdullah, Actualization of the Basic Concepts of Islamic Education: Reconstruction of Thought in a Review of Islamic Education Philosophy , (Yogyakarta: UII Press, 2 001), 68

${ }^{25}$ Ramayulis, Islamic Education, ( Jakarta: Kalam Mulia, 1994), 13-14.

${ }^{26}$ Muhammad Rasyid Ridha, Tafsir al-Manar, (Egypt: Dar al-Manar, 1373), Juz I., 143-151
} 
education. These things, among others; Respect for human reason, scientific guidance, do not oppose human nature, and maintain social needs.

The Qur'an has a vast and large treasury for the development of human culture. It is the most complete source of education, be it social, moral, spiritual, material education and the universe. The Qur'an is an absolute and whole source of value. Its existence will never change. The possibility of change only limited to human interpretation of the text of the verse that requires the dynamism of its meaning, in accordance with the context of the times, situations, conditions, and human ability to interpret. This is a normative-theoretical guideline for the implementation of Islamic education which requires further interpretation. Its contents cover all human dimensions and are able to touch all human potential, be it motivation to use the senses in interpreting the universe for the benefit of further formulations of human education (Islamic education), motivation for humans to use their minds, through the parables (tamsîl) of Allah SWT in the Qur'an ', As well as motivation so that humans use their hearts to be able to transfer the values of Divine education and so on. All of these processes are general systems of education offered by Allah. in the Qur'an so that humans can draw conclusions and carry out all these instructions in their lives as best they can.

Mourice Bucaille admired the contents of the Qur'an and said that the Qur'an was an objective holy book and contained instructions for the development of modern science. The content of his teachings is very perfect and does not conflict with the findings of modern science. From the interpretation of the ideas contained in the Qur'an, modern science can develop rapidly and play its role in building this world. ${ }^{27}$ According to Abdurrahman Saleh, because the Qur'an provides a view that refers to life in this world, then its basic principles must give guidance to Islamic education. One can not possibly talk about Islamic education if without taking the Qur'an as the only reference. ${ }^{28}$

Therefore, the implementation of Islamic education must always refer to the sources contained in the Qur'an. By sticking to the values contained in the Qur'an, especially in the implementation of Islamic education, will be able to direct and deliver dynamic-creative people and be able to achieve the essence of ubudiyah values in its Creator. With this attitude, the process of Islamic education will always be directed and able to create and deliver output as a quality human being and responsible for all the activities he does. This can be seen that

\footnotetext{
${ }^{27}$ Maurice Bucaille, Bible, Qur'an and Science, Terj. HMRasyidi, (Jakarta: Bulan Bintang, 1979), 375

${ }^{28}$ Abdurrahman Saleh Abdullah, Educational Theories Based on the Qur'an, trans. HM Arifim and Zainuddin, (Jakar ta: PT. Rineka Cipta, 1994), 20
} 
almost two-thirds of the verses of the Qur'an contain values that civilize humans and motivate humans to develop them through the educational process .

From here, the Qur'an has a mission and educational implications that are imperative, motivational, and dynamic-persuasive, as a whole system of education and democracy through human processes. The educational process is based on the spiritual and physical abilities of each individual student, gradually and continuously, without forgetting the interests of the times and Divine values. All of these Islamic educational processes are conservation and transformation processes, and internalization of values in human life as desired by Islamic teachings. With this effort, students are expected to be able to live in harmony and balance, both in life in the world and the hereafter.

b) Al-Sunnah (al-Hadit)

The word al-Hadīts etymologically means "communication, story, conversation, whether in a religious or worldly context, or in the context of history or actual events and events. ${ }^{29}$ According to al- Shubhi al-Salih, the word al-Hadit is also an isim form of tahdits, which means to inform, preach. Based on this understanding, then every word, deed or determination (taqrîr) that is based on the Prophet $\mathrm{S}$ aw. named after al-Hadit. ${ }^{30}$ From this definition, al-Hadits has three forms. First, al-Hadìts qauliyah, which contains the words and statements of the Prophet Muhammad. Second, al-Hadīts fi'liyah, which contains actions and deeds done by the prophet. Third, alHadîts taqririyah, which is the Prophet's approval of the actions and events that occurred.

Al-Hadith is the second source of Islamic provisions after the Qur'an. He is a reinforcer and explanatory of various problems both in the Qur'an and those faced in the problems of the lives of Muslims who are addressed and practiced by the Prophet Muhammad. which can be used as a foundation for Islamic education.

The position of al-Hadit in Islamic life and thought is very important, because in addition to strengthening and clarifying various problems in the Qur'an, it also provides a more concrete rationale regarding the application of various activities that must be developed within the framework and life of Muslims. Many al-Hadits of the Prophet have relevance to

\footnotetext{
${ }^{29}$ Muhammad Mustafa Azami, Studies in Hadith Methodology and Literature, (Indianapolis, Indiana: Ameri can Trus Publications, 1992), 1

${ }^{30}$ Subhi al-Salih, Ulum al-Hadith wa Musthalahuhu , (Bairut: Dar al-Ilmi li alMalayin, 1973), 3-4
} 
the rationale and direct implications for the development and application of education. and as a reference that can be used by Muslims in all their life activities. Although in general the largest part of Islamic shari'ah is already contained in the Quran, but the content has not set various dimensions of the activities of the life of the ummah in detail. Explanation of shari'ah contained in the Qur'an is still partly global. For this reason, the existence of the Prophet's alHadīts is needed as an explanatory and reinforcer for the existing Qur'anic laws, as well as guidance for the benefit of human life in all its aspects. ${ }^{31}$

From this it can be seen how the position and function of the Prophet's al-Hadith as the main source of Islamic education after the Qur'an. Its existence is a source of scientific inspiration that contains the decisions and explanations of the prophet from the Divine messages that are not contained in the Qur'an, nor those contained in the Qur'an, but still need further explanation in detail.

"Whoever is obedient to the Apostle, indeed he also obeys to Allah" (QS.al-Nisâ, 4: $80)$.

"What the Apostle gave you, take it. And what is forbidden for you, leave it ... "(QS.alHasr, 59: 7).

From the above verse, it can be clearly seen, that the position of al-Hadits of the Prophet is the main basis that can be used as a reference for the implementation of Islamic education. Through examples and regulations given by the Prophet, is a form of implementation of Islamic education that can be copied and used as a theoretical or practical reference. $^{32}$

In line with the above restrictions, Robert L. Gullick, as cited by Jalaluddin Rahmat, ${ }^{33}$ acknowledged the existence of the Prophet as the most successful educator in guiding humanity towards the happiness of life, both in this world and the hereafter. The process shown by the Prophet can be used as a basic reference in the implementation of Islamic education.

${ }^{31}$ NP. Aghnides, Muhammadan Theorities of Finance: With an Introduction to Muhammadan Law and a Bibliography, (New York: AMS Press, 1969), 35.

32 Jalaluddin and Usman Said, Philosophy of Islamic education: Concepts and Development of His Thought, (Jakarta: Rja Grafindo Persada, 1994), 37

${ }^{33}$ Robert L., Gullict, in Jaluddin Rahmat, Islam Alternat if, (Bandung: Mizan, 1991), 115 
In the context of Islamic education, the reference can be seen from two forms, namely: First, as a syar'yyah reference: which includes the main contents of Islamic teachings theoretically. Second, the operational-applicative reference which covers the way the Prophet played his role as an educator and at the same time as a fair evaluator and still upholds the values of Islamic teachings. It can be seen from the way the Prophet carried out the teaching and learning process, so that in a short time he was able to be absorbed by his friends, the evaluation carried out so that it was effective and efficient, personal charisma and spirit that must exist in an educator who had been shown by the Prophet, the Prophet's way in choosing materials, props, and conditions that are so adaptive, as well as the Prophet's way of placing students' positions, and so on. All of these are figures that exist in the Prophet. and become a model for all human activities as uswah al-hasanah ${ }^{34}$ which has been guided directly by Allah SWT.So that it is almost impossible to make mistakes in the implementation of the education process.

The process of Islamic education shown by the Prophet Muhammad. is a form of implementation of education that is flexible and universal, in accordance with the potential possessed by students, the habits of society and the natural conditions in which the educational process takes place wrapped by pillars of Islamic faith.

In this context, Islamic education carried out by the Prophet can be divided into forms, namely: First, the pattern of education when the Prophet was in Mecca. At this time, the Prophet exploited the potential of the people of Mecca by inviting him to read, pay attention and think about the power of God, both in the universe and in him. Continuing the tradition of making beautiful poems with Islamic nuance, as well as reading the verses of the Qur'an, changing the habits of the people of Mecca who had started a job to mention the names of idols, with the name of Allah (Basmalah), and so on. Concretely, the mapping of Islamic education in this period can be divided into four main aspects, namely: moral education and character education, and physical education (health), such as horseback riding, archery, and maintaining hygiene.

Second, the pattern of education at the time of the prophet in Medina. Geographically, Medina is an agricultural area. While Mecca is the center of trade. This distinguishes the attitudes and habits of the people in the two regions. The Medina community is a community of farmers who live helping one another. Seeing this condition, the pattern of education

\footnotetext{
${ }^{34}$ Surah al-Ahzab, 33: 21
} 
applied by the Prophet SAW. more oriented towards the consolidation of the values of brotherhood between the muhâjirîn and anshâr on one bond. To realize this, the prophet first established the mosque as an effective means. The educational material is more focused on planting monotheism, family education, community education, and manners (adab). All of this was quite effective, because, in addition to the internal motivation of the people at that time, the charisma and methods used by the Prophet were able to protect all the interests of the community fairly and democratically._By referring to this pattern, Islamic education becomes a formidable and adaptive tool in delivering its students to build Islamic-nuanced civilizations (rahmatan li al-'alamin).

\section{c) Islamic Thought (Ijtihâd)}

What is meant by Islamic thought is the use of human reason in order to provide meaning and actualization of various Islamic teachings. So that it can be adjusted to the demands of society and the development of the times that arise in the life of mankind in various forms of problems to find solutions that are in accordance with Islamic teachings. This effort is very important in order to translate Islamic teachings while responding to the development of Islamic teachings in accordance with the times, from time to time since then until now.

Islamic thought needs to be monitored, continued and developed in accordance with the needs and problems encountered. It is a valuable and important contribution to be developed in the world of Islamic education. Herein lies the importance of Islamic thought which is an integral part, which can be both a source and a source within the framework of Islamic education.

Islamic thought rests on the results of ijtihâd, as the third source of Islamic law after alQur'an and al-Hadith. Ijtihâd means hard and earnest (persistent) efforts made by the scholars, to establish, a law, a case or a determination on a particular issue. Whereas in terminology, according to the limits developed by al-Amidî, is an expression of the agreement of a number of ahl al-hâl wa al-'aqd (ulil amn) of the people of Muhammad in a time, to establish sharia law against various events that occurred. Meanwhile, according to Abu Zahrah, ijtihad is a product of ijma '(agreement) of Muslim mujtahid, in a certain period, on various problems that occur, after the death of the Prophet Muhammad, to establish syariah law' on various religious practices of the ummah. ${ }^{35}$

${ }^{35}$ Muhammad Abu Zahrah, Usul al-Fiqh , (Dar al-Fikr al-Arabi, tt), 156 
From the above restrictions, it can be seen, that ijtihad, basically is a process of excavating and establishing sharia law carried out by Muslim mujtahids, using the reasoning approach, and other approaches: qiyas, masalih al-mursalah, 'urf, and so on , independently, in order to provide legal answers to various problems of the Ummah which, according to the provisions of the law, are sharply absent from al-Qu r 'an and Al-Haditts Rasulullah. ${ }^{36}$ Therefore, the analytical field of study of ijtihad, is a fairly large field of study. The extent includes all aspects of human life that are so varied and dynamic, in tune with the development of the acceleration of the demands of the times, including aspects of education, as one aspect that can not be separated from the dynamic life of humans.

al-Qur'an and al-Hadith are the legal basis that is needed, especially after the Prophet Muhammad SAW, at any time in order to deliver humans in responding to the challenges of an increasingly globalized and mondial era. Because the development of the era is so dynamic and always changing, the existence of ijtihâd must always be dynamic and always renewed, in tune with the sequence of the development of the times, as long as it does not conflict with the basic principles of the Qur'an and al-Hadits. The need to perform ijtihâd dynamically and always be updated and followed up by Muslim mujtâhid in accordance with human development and needs, is an absolute thing that must be done. This is because not all dimensions of human life are explained in detail in the Qur'an and Hadits. Most are only normative laws that are mutasyabihat. For this process, according to al-Sayuthi, it is required that each period requires a person or group of people who are able to play the role of mujtahid. ${ }^{37}$

Therefore, along with the development of increasingly globalized and urgent times, making the existence of ijtihâd, especially in the field of education, is absolutely necessary. The goal of educational ijtihad is not only limited to the field of material or content, curriculum, methods, evaluation, or even facilities and infrastructure, but also covers the entire education system in a broad sense .

The need to perform ijtihâd in the field of education, especially Islamic education, because educational media are the main means of building social and cultural institutions of human life. This indication gives the meaning, that the progress or decline of human culture develops dynamically or not, is very much determined from the dynamics of the education

\footnotetext{
${ }^{36}$ Abdullah Ahmed al-Na ' im, Shari'a Deconstruction, Terj. Ahmad Suaedy and Amiruddin Arran i, (Yogyakarta: LKIS, 1994), 53.

${ }^{37}$ MA. Sahal Mafudh, Nuance Fiqh Sosia 1, (Yogyakarta: LkiS, 1994), 40
} 
system implemented. The dynamics of ijtihâd in connecting humans to dynamic life must always be a reflection and incarnation of the basic values and principles of the Qur'an and the Hadith. This process will be able to control all human activities, as well as a means to draw closer to his Lord.

In the world of education, ijtihad's contribution in actively organizing a dialogical education system has quite a big role and influence. For example in setting educational goals to be achieved. Although in general the formulation of these objectives has been mentioned in the Qur'an, ${ }^{38}$ but in particular, these objectives are methihki dimensions that must be developed in accordance with the demands of human needs on a particular period, which is different from previous periods.

\section{Islamic education in the Quran}

If we talk about the goals of Islamic education, it means talking about ideal values that are Islamic. While the idealism of Islam itself is essentially contains the value of human behavior based on faith and piety to God as a source of absolute power that must be obeyed.

The term "goal" etymologically means direction, purpose or direction. In Arabic, "goal" is called "Maqāshid". While in English it is termed "goal, purpose, objectives or aim." In terminology, goal means something that is expected to be achieved after an attempt or activity is completed. An expected destination is reached after a business or activity completed an insane ksanakan. ${ }^{39}$ Therefore, education which is a business that has a certain process to be achieved as an indication of the success of education.

In general, educational objectives have two theoretical views. First, social oriented, which is a view that expresses education as the main means of creating people. Second, oriented towards individuals, who are more focused on the needs and interests of students. ${ }^{40}$

The educational goals of Islam according to Muhammad Fadhil alJamaly, Islamic educational purposes according to the Qur ' an include; (1) explains the position of students as humans among other creatures of God and their responsibilities in this life. (2) explains the relationship as a social creature and its responsibilities in the fabric of social life. (3) explains the relationship between humans and nature and its task to know the wisdom of creation by

\footnotetext{
${ }^{38}$ QS, al-Dzariyat, 52: 56

${ }^{39}$ Zakiah Darajat, Islamic Education. ( Jakarta: Bumi Aksara, 2011), 2

${ }^{40}$ M. Jindar Wahyudi, Reason of Qur'an Education, (Yogyakarta: Ap eiron Philotes, 2006), cet.I, 29
} 
prospering the universe. (4) explains its relationship with Khaliq as the creator of the universe. $^{41}$

Practically, Muhammad Athiyah al-Abrasyi, concluded that the objectives of Islamic education consist of 5 objectives, namely: (1) forming noble morals (2) preparing world life and the hereafter (3) preparation for seeking good fortune and maintaining its usefulness (4) growing the scientific spirit among students (5) prepares skilled professionals. ${ }^{42}$

Quraiy Syihab argues that the purpose of Islamic education (al-Quran) is to foster human beings individually and in groups so that they can carry out their functions as His servants and caliphs in order to build this world in accordance with the concepts set by God. Meanwhile, according to Al-Ghazali the purpose of education is to draw closer to Allah, not rank and boast, and let a student learn not to deceive fools or boast. So education is not out of moral education. ${ }^{43}$

The purpose of education according to Qardhawi is not limited to forming humans able to relate vertically to Allah SWT, but education is more emphasized on the element of creating people who are ready to navigate life in various situations and prepare students to be able to live in society in a variety of turmoil. Education in the level of practice also aims to deliver every student to maturity both in mental, emotional, moral, intellectual and spiritual aspects. So the material offered by Qardhawi covers: al-imaniyah (faith education), alkhuluqiyah (moral education), al-jismiyah (physical education), alaqliyah (mental education), al-nafsiyah (soul education), al-ijlimaiyah (social education), and al-jinisiyah (sex education). ${ }^{44}$

According to Hamka and Samsul Nizar explained that Islamic education aims to form al-insan al-kamil or perfect human. Moving on from this concept, then at least Islamic education should be directed at two dimensions. In this case, namely; the dimension of

\footnotetext{
${ }^{41}$ Abdul Mujib and Jusuf Mudzakir, Islamic Education, (Jakarta: Kenca na Prenada Media Group, 2014), 83

${ }^{42}$ Abdul Mujib and Jusuf Mudzakir, Islamic Education, (Jakarta: Kencan a Prenada Media Group, 2014), 83

${ }^{43}$ Abd. Ranchman Assegaf, School of Islamic Education Thought, (Jakarta: PT Raja Grafindo Persada, 2013), 112

${ }^{44}$ Safrudin Aziz, Islamic Education Thought, (Yogyakarta: KALIMEDIA, 2015), 169
} 
horizontal dialectics with respect to fellow human beings and the dimension of vertical submission to God. ${ }^{45}$

Meanwhile, Yasin believes that the function of educational objectives includes three aspects, all of which are still normative. First, it provides direction for the education process. Second, provide motivation in educational activities, because basically educational goals are educational values to be achieved and internalized in students. Third, the purpose of education is a criterion or measure in the evaluation of education. ${ }^{46}$

There are several opinions of experts regarding the objectives of Islamic education. First, Ibn Khaldun argues that the aim of Islamic education is ukhrawi and worldly oriented. Islamic education must shape humans as servants who obey God and form humans who are able to face all forms of world life problems. ${ }^{47}$ Second, al-Ghazali formulated the aim of Islamic education into two aspects, namely forming a complete human being who aims to draw closer to Allah and to the happiness of life in the world and the hereafter. According to al-Ghazali that the aim of Islamic education is human perfection in the world and the hereafter. Humans can achieve perfection through the use of knowledge. With these virtues, it will give him happiness in the world as well as a way to draw closer to God for ultimate happiness. $^{48}$

Examining these two formulas, the goal of Islamic education includes two main aspects, namely realizing the happiness of life in the world and happiness in the hereafter. This illustrates that Islamic education is a complete education that summarizes the purpose of human life as a creature of God's creation that is complete and equipped with reason. However, it should be noted here, the development of social behavior which is quite volatile and unpredictable, requires a reinterpretation of the objectives of Islamic education which is specific and applicable. Al-Quran and Hadith which are the main footing can be reinterpreted by combining the socio-cultural values that have been the foothold of the Indonesian people as friendly and tolerant Eastern people. To explore the goals of education based on socio-cultural values it needs to be seen based on aspects of ontological, epistemological, and axiological studies .

\footnotetext{
${ }^{45}$ Samsul Nizar, Discussing Intellectual Dynamics and Hamka Thinking about Islamic Education, (Jakarta: Prenada Me dia Group, 2008), cet. 1st, 116th

${ }^{46}$ Yasin, A. F, Islamic Education Dimensions . UIN-Maliki Press, 2008), 98

${ }^{47}$ Zubaedi, Philosophy of Islamic Education am. (Yogyakarta: Student Library, 2012), 32

${ }^{48}$ Zainuddin, et al . Islamic education. ( Malang: UIN Malang Press , 2019), 71
} 
Al-Quran and Sunnah are the main sources of Islamic law throughout the world. Both of these primary sources apply throughout the ages. That means the Quran and Sunnah apply from the time the Prophet Muhammad was appointed as an Apostle until life in this world ends. The heterogeneity of Muslims with diverse schools recognizes and uses the Quran and al-Hadith as two main sources. Of course the level of understanding, interpretation, comprehension and implementation of the norms of the Quran and Sunna cannot be equated just like that between one region and another. Local socio-cultural problems play a role in giving different patterns of understanding to one another. ${ }^{49}$

Although the normative understanding is still needed, it has some weaknesses. First, the paradigm lacks a historical, sociological, and anthropological basis. Resulting in a gap between theory and practice. Second, the paradigm is less able to appreciate the rapid development of social sciences, humanities, science and technology.

Thus in addition to standing on the qauli verses, Islamic education must also be based on the qauni verses. In this perspective, integration needs to be done between general science, namely universal verses or unwritten revelations (kauniyyah) and religious knowledge, namely verses of the Quran or written revelations (qauliyyah). ${ }_{-}^{50}$ The roots of the backwardness of the Muslim world in science and technology today are due to the dichotomy between religion and general science. This happened for centuries after the collapse of the Abbasid Caliphate which caused a traumatic sense for Muslims to study the discipline of rationality. To realize the goals of Islamic education that are scientific, humanist and religious (insan kamil), the discourse of Islamic education must change the dichotomic paradigm to the integristic-interconnected paradigm between science and religion .

The objectives of education in the Quran can be summarized as follows: 1) Introducing man to his role among fellow commandments (beings) and his personal responsibilities in life. 2) Introducing humans to their social interactions and responsibilities in social life. 3) Introducing humans to nature and inviting them to know the wisdom of creating it and giving them the possibility to benefit from it. 4) Introduce mankind to the creator of this nature (Allah) and command worship to Him.

\footnotetext{
${ }^{49}$ Abdullah, M. A , Islamic Studies in Higher Education: an Interactive Interconnected Integrity Approach . (Student Library, 2006), 10

${ }^{50}$ Minhaji, A, Academic Traditions in Higher Education, (Yogyakarta: Suka Press, 2013), 32
} 
We can understand that the first three goals are the means to an end, thus it is clear that the main goal of Islamic education is ma'rifatullah and devotion to Him, while ma'rifat (knowing) oneself, society, and the rules of nature is nothing but a mere the means that lead us to ma'rifatullah.

According to Zubaedi the objectives of Islamic education can be classified into four types: 1) Physical Education Objectives (al-Ahdaf al-Jismiyah), in some aspects, Islamic education aims to prepare humans for the duty of caliphs on earth through physical skills. 2) The Purpose of Spiritual Education (al-Ahdaf ar-Ruhaniyah), in some aspects, Islamic education aims to increase the soul and loyalty which is only for God and implement Islamic morality exemplified by the Holy Prophet based on the ideal ideals in al- The Quran. 3) The Purpose of Intellectual Education (al-Ahdaf al-Aqliyah), in some aspects, Islamic education aims at directing intelligence to find the truth and its causes by examining the signs of God's power. This stage of resourceful education is the attainment of scientific truth, empirical truth, and metaempiris or philosophical truth. 4) The purpose of Social Education (al-Ahdaf al-Ijtima'iyyah), in some aspects, Islamic education aims to form a whole personality both spirit, body and mind. ${ }^{51}$

The purpose of Islamic education is thus a depiction of Islamic values that will be realized in the personal person of students at the end of the process. In other terms, the goal of Islamic education is the embodiment of Islamic values in the human person of the student educated by Muslim educators through a terminal process on the product (product) of an Islamic personality who is faithful, devoted, and knowledgeable who is able to develop himself into a servant of God who is God. obedient.

In addition to the orientation of Islamic education above, there are other objectives to be achieved by Islamic Education. Seeing the explanations of the Tafsir scholars, the writer draws a red line that in the three verses there is a concept of social goals in Islamic education. This is marked by Allah SWT. reduce the Prophet from his own kind.

Every community wherever they are, usually has traditional values that have been agreed upon and shared and adhered to together. Both positive and negative values. Prophet Muhammad SAW. sent by Allah SWT. in the Arab country at that time the people he faced were the Arab Jahiliyyah community. Islam in the face of positive values that already exist

${ }^{51}$ Zubaedi, Philosophy of Islamic Education am . (Yogyakarta: Student Library, 2012), 37 
will always motivate and support. However, with negative values, Islam will reject and straighten it.

In Ahmad Munir's work entitled Tarbawi Tafsir Revealing the Message of the Qur'an about Education, that in the view of the Qur'an, a change will be carried out if it is fulfilled by two basic conditions namely; firstly, there are values or ideas, secondly there are actors who adjust to these values. The first conditions are contained in the instructions of the Quran and the explanation of the Prophet Muhammad. The second condition is humans who live in a place and are bound by the laws of society that have been set. In this case humans are both agents of change and who create history. ${ }^{52}$

Humans are as social agents of change, i.e. humans as modifiers of the conditions in their surroundings. In accordance with capabilities, humans are able to provide ideas or concepts that will be carried forward in accordance with the times.

The role of humans as khalifah fil ardhi, very clearly shows that humans have a central role in social matters. Education that denies the social impulse of the caliph must be thus maintained. Education that denies the social impetus for each individual student, is education that does not have adequate reasons. ${ }^{53}$ This means that the goal of Islamic education if it does not produce social goals, then an impossibility. Because the purpose of Islamic education will indirectly encourage a sense of unity and a sense of belonging to members with their groups. So automatically the goal of social education in Islam is definitely there.

Likewise, the three verses illustrate that there are three stages towards social objectives in Islamic education. which Allah verses recite. SAW Rasul. your verses to

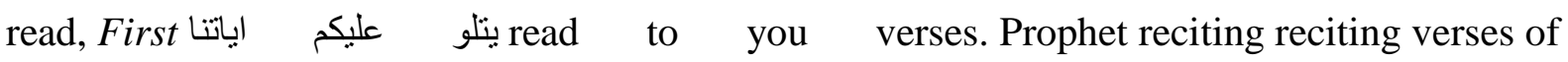
God m embimbing to the right path, R Asul SAW. give directions to the path of guidance. Hidayah are the verses of the Quran and others which are evidence and

${ }^{52}$ Ahmad Munir, Tafsir Tarbawi Reveals the Message of the Qur'an about Education, (Yogyakarta: TERAS, 2008), 184.

${ }^{53}$ Abdurahman Shaleh Abdullah, Educational Theory A Qur'anic Outlook, trans. Educational Theories in the Quran, trans. M. Arifin, (Jakarta a: PT Rineka Cipta, 2007), 149. 
propositions that show the unity and majesty of Allah SWT, and show the wisdom of Allah SWT. the almighty set the order of heaven and earth. ${ }^{54}$

The Prophet Muhammad read the verses to his people. This is a form of the Prophet's concern for his people. The Prophet gave news or gave knowledge to his people so that his people knew that the usual activities were not in accordance with the concept of Islam.

Prophet Muhammad SAW. patiently guide them even though their people are in a state of ignorance. Prophet Muhammad SAW. is as the main educator for his people. He gave knowledge through a simple but striking strategy to his people, namely the process or stage as recommended in the Qur'an then he applied. Not only his theory, but also his practice.

Second, ويزكيهم ( Cleaning ). In fact Muhammad purified and cleansed their souls from false creeds, wasaniy persuasions and their impurities. Because, the Arabs and others before Islam, lived in chaos morals, creeds and ethics. Then the Prophet Muhammad. uprooting them from the roots of wasaniy and removing the inner roots from their creeds. Like their belief that behind the natural causes associated with these events, there are also benefits that can be expected and the dangers that are feared. This arises from some creatures. ${ }^{55}$

Rasulullah SAW. cleanse the soul of mankind from various abject despicable acts, such as rampant jahiliyyah habits. For example, burying a girl alive, killing a child with the intention of alleviating the burden of livelihood, and fond of bleeding because of a very trivial matter. Besides that, Rasulullah SAW. always plant noble moral seeds, so that you become human beings who have moral mercy.

Third, ويعلمهم الكتاب و الحكمة (and teaches books and wisdom). The Prophet SAW. teach them al-Kitab (Qur'an) and Wisdom (Hadith). Teaching al-Kitab means forcing them to want to learn to write and free them from illiteracy to light and science. The Prophet SAW. ask them to write the Qur'an and he forms the secretaries of revelation. ${ }^{56} \mathrm{He}$ also has taught the Qur'an and useful wisdom, which we can learn from his words and deeds. He is the prime example and great leader who guides His people to the right path and leads it to science in all its forms. ${ }^{57}$

${ }^{54}$ Ahmad Musthafa Al-Maraghi, Tafsir al-Maraghi, (Semarang: PT. Karya Toha Pu Tra Semarang, 1993), Juz 2, 28.

${ }_{55}^{55}$ Al-Maraghi , Tafsir al-Maraghi, Juz 4, 216.

${ }^{56}$ Al-Maraghi , Tafsir al-Maraghi, Juz 4, 217.

${ }^{57}$ Hasbi Ash-Shiddieqy, Tafsir Al-Qur'a nul Majid An-Nur, Volume 4, 336. 
After the Prophet Muhammad purified them, the next way was to teach the book and wisdom. The Bible in this case many interpret as the Quran or the basic guide of Islam before the hadith. He introduced to his people that in the Quran there are many straight guides and explanations. All of this is contrary to the teachings in the Qur'an. By doing so he indirectly teaches change to the community. Furthermore, the Prophet Muhammad. teach Al-Wisdom, there are some scholars who interpret Al-Wisdom is a hadith. To understand the Qur'an it is very necessary wisdom or hadith. According to Muhaimin, Teaching in the verse mentioned earlier, includes theoretical and practical, so that students get the policy and skills to carry out things that bring benefits and reject harm. This teaching also includes science and al-Hikmah (wise). ${ }^{58}$

In the opinion of the writer, Al-Hikmah can also be interpreted as social values and policy. So the Prophet Muhammad. teach social values in the sense of wisdom. This wisdom is more interpreted as wisdom in fostering Islamic society towards glory and integration.

In the three verses of the Quran, Qur'an Surah Al- Baqarah: 151, Al-Imran: 164, and Al-Jumu'ah: 2. L afadh ويعلمكم مالم تكونو تعلمون illustrated that the Prophet Muhammad was able to teach new things that had not been known before. Teaching that is not sourced from reason and analysis. That knowledge can only be obtained through revelation, such as the preaching about the unseen nature, the journey of the Prophets and previous narratives that still seem unclear to you, and stories that are completely unknown to the scribes. ${ }^{59}$

Then complete with the pronunciation وإن كانو من قبل لفي ضلال مبين(Truly they were before the Prophethood in a real error). Because there is no error that is more severe than the error of a polytheist to Allah SWT. by worshiping idols, and they indulge their fantasies. Prophet Muhammad . managed to bring the people of ignorance or get lost into an enlightened people or get emanated faith. The ancient Arabs called jahiliyah, does not mean they are stupid, rather they have extraordinary intelligence. This is proven by his very strong memorization. This also causes the writing tradition of yore in Arabic to not exist. They are called jahiliyyah because from a spiritual point of view they do not know at all. They associate partners with Allah, make shirk and act dhalim.

\footnotetext{
${ }^{58}$ Muhaimin, Development of Islamic Religious Education Curriculum; in Schools, Madrasas, and Universities, (Ja krta: Rajawali Press, 2005), 45.

${ }^{59}$ Al-Maraghi, Tafsir al-Maraghi, Juz 2, 30
} 
As described by Omar, Islam seeks to promote and integrate the society on the principle - the principle of religion and morals done justice, equal opportunities, blend, the narrowness of the gap, and cooperation among factions and individuals within the community. That way it will create social change in a compact and more significant way. In addition, relationships will also be created between humans based on self-esteem, truth, justice, cooperation, solidarity, harmony, respect-respect, compassion, maintaining public benefit, and eliminating damage on earth.

P Education in Islam is essentially focussed on three things. First, the formation of human beings ka (perfect human) who has a qur'ani dimension in his life. According to Iqbal as quoted by Dawam, the criteria of the people are believers who have strength, insight, deeds, and wisdom in themselves and have the qualities reflected in the Prophet's personality in the form of noble character. ${ }^{60}$ Meanwhile, according to Ahmad Tafsir in his book Education in the Islamic Perspective, the perfect human being has physical indicators that are healthy, strong, and skilled, intelligent and smart, and of high quality. ${ }^{61}$

Kedu a, the creation of man ka ffah which has dimensions of religious, cultural, and scientific. The religious dimension, namely humans are creatures that contain various mysteries and cannot be reduced to certain factors alone. Thus, humans can be prevented from being made into numbers, or programmed robots, but still maintain their personality, freedom of dignity. The cultural dimension, humans are ethical creatures who have obligations and responsibilities for the preservation of the entire world. In this dimension, human beings get the basis of education to maintain the integrity of their personality and are able to prevent the flow of time that leads to desintegration and fragmentation which always threatens human life. The scientific dimension, which is the dimension that encourages humans to always be objective and realistic in facing the challenges of the times, as well as various human lives to behave critically and rationally, and try to develop thinking skills and creativity. $^{62}$ 1989), 26.

${ }^{60}$ Dawam Raharjo (editor), Insan Kamil: Human Concepts According to Islam (Jakarta: Temprint,

\footnotetext{
${ }^{61}$ Ahmad Tafsir, Education in Islamic Perspectives, Cet. 6 (Bandung: PT Remaja Rosdakarya, 2005), 41-46.

${ }^{62}$ Muhammad Tholhah Hasan, Islamic Prospects in Facing the Challenges of the Age . (Jakarta: Bangun Prakarya, 1986), 43-44.
} 
Third, awareness of human functions as servants, the Khalifah of Allah, as well as warathah al-anbiya ' and provide adequate provisions in the context of carrying out these functions. Fadhil al-Djamaly, as quoted by al-Syaibany, explained that education based on the Quran had four main objectives. First, it introduces man to his position among God's creatures, introduces the individual responsibility of his life. Second, introducing humans to social interactions and responsibilities in order to be harmonious in a social system. Third, introduce to humans the Creator of this nature. Fourth, introducing human beings to creatures (nature), and inviting them to understand the wisdom of their creation, and enable humans to use them. ${ }^{63}$

Education in the perspective of the Quran is education that focuses on fostering people individually and in groups so that they can carry out their functions as servants of Allah and His Khalifah in order to build this world in accordance with the concepts established by God. If this can be realized then Muslims will be able to apply Islamic teachings comprehensively. ${ }^{64}$

So, the aim of Islamic education that originates in the Quran is to form a complete Muslim person, to develop the full potential of human beings both physically and spiritually, to foster a harmonious relationship between each person with God, man, and the universe. Therefore, in terms of achieving its objectives, education in the view of the Quran aims at the formation of Muslims who are able to establish communication, interaction, and connections in three ways. Namely h \} abl min Alla h (relationship with God), habl min al$n a$ 's (relationship with sesam a human), and $h$ abl min al-' $a$ lam (relationship with nature). ${ }^{65}$

\section{Conclusion}

From the discussion above, it can be concluded that the concept education in the Quran can be referred to several words that have the root of the word is identical to the meaning of education, including rabba, is the root word tarbiyah. The purpose of Islamic education is found in the Quran is not only the transfer of knowledge, however also a value transfer process. These objectives are related to build habl min min Allah, habl min al-nas,and habl min al-'a lam. Meanwhile, in terms of social change, the purpose of education is realize

${ }^{63}$ Omar Mohammad al-Toumy al-Syaibany, Philosophy of Islamic Education (Jakarta: Crescent Star, 1979), 419-420

${ }^{64}$ Mah mud Sayyid Sultan, Buhuth fi al-Tarbyah al-Islamiyah (Cairo: Dar al-Ma'arif, 1979), 53

${ }^{65}$ Haidar Putra Daulay, Islamic Education in the National Education System, Cet. 1. Jakarta: Kencana, 2004. 153 
social diversion. While in terms of human needs individually the goal is to create a balanced development physical, psychological, and intelligent. So the purpose of education in the perspective of al The Qur'an focuses on three things. First, to print humans plenary in the joints of his life. Second, to create comprehensive human being from the dimensions of religion, culture, and science. Third, to create humans who are aware of their function as servants Allah and the heir to the Prophet. Some of these goals, their essence for form a Muslim figure rahamatan li al-'alamin

\section{Reference}

Abd. Ranchman Assegaf, School of Islamic Education Thought, (Jakarta: PT Raja Grafindo Persada, 2013), 112

Abdul Mujib and Jusuf Mudzakir, Islamic Education, Jakarta: Kencana Prenada Media Group, 2014.

Abdullah Ahmed al-Na 'im, Shari'a Deconstruction, Terj. Ahmad Suaedy and Amiruddin Arrani, Yogyakarta: LKIS, 1994.

Abdullah, M. A, Islamic Studies in Higher Education: an Interactive Interconnected Integrity Approach . Student Library, 2006.

Abdullah, Rahman, Actualization of the Basic Concepts of Islamic Education: Reconstruction of Thought in a Review of Islamic Education Philosophy, Yogyakarta: UII Press, 2001.

Abdurahman Shaleh Abdullah, Educational Theory A Qur'anic Outlook, trans. Educational Theories in the Quran, trans. M. Arifin, Jakarta a: PT Rineka Cipta, 2007.

Ahmad Musthafa Al-Maraghi, Tafsir al-Maraghi, Semarang: PT. Karya Toha Pu Tra Semarang, 1993.

Alim, M, Islamic Education , (Jakarta: Grafindo, 2006)

Ar-Rasyidin and Samsul Nizar, Philosophy of Islamic Education, Ciputat: PT Ciputat Press, 2005.

Aziz, Safrudin, Islamic Education Thought, Yogyakarta: KALIMEDIA, 2015.

Aziz, Safrudin, Islamic Education Thought, Yogyakarta: KALIMEDIA, 2015.

Azra, Azyumardi, Muslim Intellectual Essays and Islamic Education, Jakarta: Logos Discourse of Science, 1999.

Darajat, Zakiah, Islamic Education. Jakarta: Bumi Aksara, 2011. 
Dawam Raharjo (editor), Insan Kamil: Human Concepts According to Isla, Jakarta: Temprint, 1989.

Fatah Jalal, Abdul, Principles of Islamic Education, Terj. Herry Noer Ali, Bandung, CV . Dipenegoro, 1988.

Hasnunidah, N., \& Susilo, H. "Profile of Students' Sociocultural Perspectives in Arguing Basic Biology Courses", In Proceeding Biology Education Conference: Biology, Science, Environmental, and Learning, 11: 1 , (2014): 729- 733

Hidayat, S., \& Wakhidah, AN (2015). The Concept of Islamic Education Ibn Khaldun Is Relevant to National Education, Profession : Journal of Islamic Studies, 1: 93 (2015):102.

Jalaluddin and Usman Said, Philosophy of Islamic education: Concepts and Development of His Thought, Jakarta: Rja Grafindo Persada, 1994.

MA. Sahal Mafudh, Nuance Fiqh Sosial, Yogyakarta: LkiS, 1994.

Mahmud Sayyid Sultan, Buhuth fi al-Tarbyah al-Islamiyah, Cairo: Dar al-Ma'arif, 1979.

Maurice Bucaille, Bible, Qur'an and Science, Terj. HMRasyidi, Jakarta: Bulan Bintang, 1979.

Minhaji, A, Academic Traditions in Higher Education, Yogyakarta: Suka Press, 2013.

Miniarti, Sri, Islamic Education, Jakarta: AMZAH, 2013.

Muhaimin, Development of Islamic Religious Education Curriculum; in Schools, Madrasas, and Universities , (Ja krta: Rajawali Press, 2005), 45.

Muhaimin, Islamic Education Paradigm, Bandung: Teens Rosdakary a, 2002.

Muhaimin, Reconstruction of Islamic Education, Jakarata: PT RAJAGRAFINDO PERSADA, 2013.

Mulyasa, E, Competency Based Islamic Religious Education. Band ung: PT Remaja Rosdakarya, 2005.

Munir, Ahmad, Tafsir Tarbawi Reveals the Message of the Qur'an about Education, Yogyakarta: TERAS, 2008.

Mustafa Azami, Muhammad, Studies in Hadith Methodology and Literature, Indianapolis, Indiana: Ameri can Trus Publications, 1992.

Nashir, A. Buya Hamka and Mohammad Natsir on Islamic Education, Journal of AtTa'dib, 3: 1, (2007): 59- 81.

Nata, Abuddin, Islamic Education, Jakarta: Kencan a Prenada Media Group, 2010.

Nizar, Samsul, Discussing Intellectual Dynamics and Hamka Thinking about Islamic Education, Jakarta: Prenada Media Group, 2008. 
Nizar, Samsul, Discussing Intellectual Dynamics and Hamka Thinking about Islamic Education, Jakarta: Prenada Me dia Group, 2008.

Nizar, Samsul, Fundamentals of Islamic Education Thought,Jakarta: First Media Style, 2001.

Nouruzzaman Shiddiqi, rapids of Muslim Civilization, Yogyakarta: Student Library, 1996.

NP. Aghnides, Muhammadan Theorities of Finance: With an Introduction to Muhammadan Law and a Bibliography, New York: AMS Press, 1969.

Omar Mohammad al-Toumy al-Syaibany, Philosophy of Islamic Education, Jakarta: Crescent Star, 1979.

Putra Daulay, Haidar, Islamic Education in the National Education System, Cet. 1. Jakarta: Kencana, 2004.

Ramayulis, Islamic Education, Jakarta: Kalam Mulia 2010.

Rasyid Ridha, Muhammad, Tafsir al-Manar, Egypt: Dar al-Manar, 1373.

Robert L., Gullict, in Jaluddin Rahmat, Islam Alternatif, Bandung: Mizan, 1991.

Rohman, M., \& Lessy, Z, "Practicing Multicultural Education through Religiously Affiliated Schools and Its Implications for Social Affairs", Journal of Islamic Education, 6: 1, (2017): 1-24.

Saleh Abdullah, Abdurrahman, Educational Theories Based on the Qur'an, trans. HM Arifim and Zainuddin, Jakar ta: PT. Rineka Cipta, 1994.

Subhi al-Salih, Ulum al-Hadith wa Musthalahuhu, Bairut: Dar al-Ilmi li alMalayin, 1973.

Tafsir, Ahmad, Education in Islamic Perspectives, Bandu : Ramaja Rosdakarya, 2013.

Tholhah Hasan, Muhammad, Islamic Prospects in Facing the Challenges of the Age . Jakarta: Bangun Prakarya, 1986.

Wahyudi, M. Jinda, Reason of Qur'an Education, Yogyakar ta: Apeiron Philotes, 2006.

Wahyudi, M. Jindar, Reason of Qur'an Education, Yogyakarta: Ap eiron Philotes, 2006.

Zainuddin, et al . Islamic education, Malang: UIN Malang Press , 2019.

Zubaedi, Philosophy of Islamic Education am , Yogyakarta: Student Library, 2012.

Zuhairini, et-al, History of Islamic Education, Jakarta: Earth Literacy, 1992. 